the beautiful symmetry and structure of the larger scales of motion. There is no mention of such models, and the only satellite picture appears, virtually without comment, on the dust cover. It is a picture of the southern hemisphere and all the cloud-whirls go the opposite way round to those in the northern hemisphere most of us are used to. It hits one as a left-handed thread does, yet it is hardly mentioned.

Many interesting facts upon which scientific inference is based are here, many concepts related to their interpretation are named, but for a scientist there is too little critical analysis of the value and usefulness of those concepts.

J. S. A. GREEN

\section{Patent Problems}

A Handbook on Patents. By H. W. Grace. Pp. viii+185. (Charles Knight: London, December 1971.) $£ 3$.

EVER since the publication of C. Lees's book Patent Protection: the Inventor and His Patent in 1965 with its inspired and readable tale of the invention of a potato peeler by a Mr I. N. Genius, there has been a need for a more up-todate introductory volume to the intricate world of patents. The chief obstacle in this field has always been the legal phraseology in which the relevant laws and their interpretations are couched and which is usually wellnigh incomprehensible to those people who most need

\title{
Communicating Cells
}
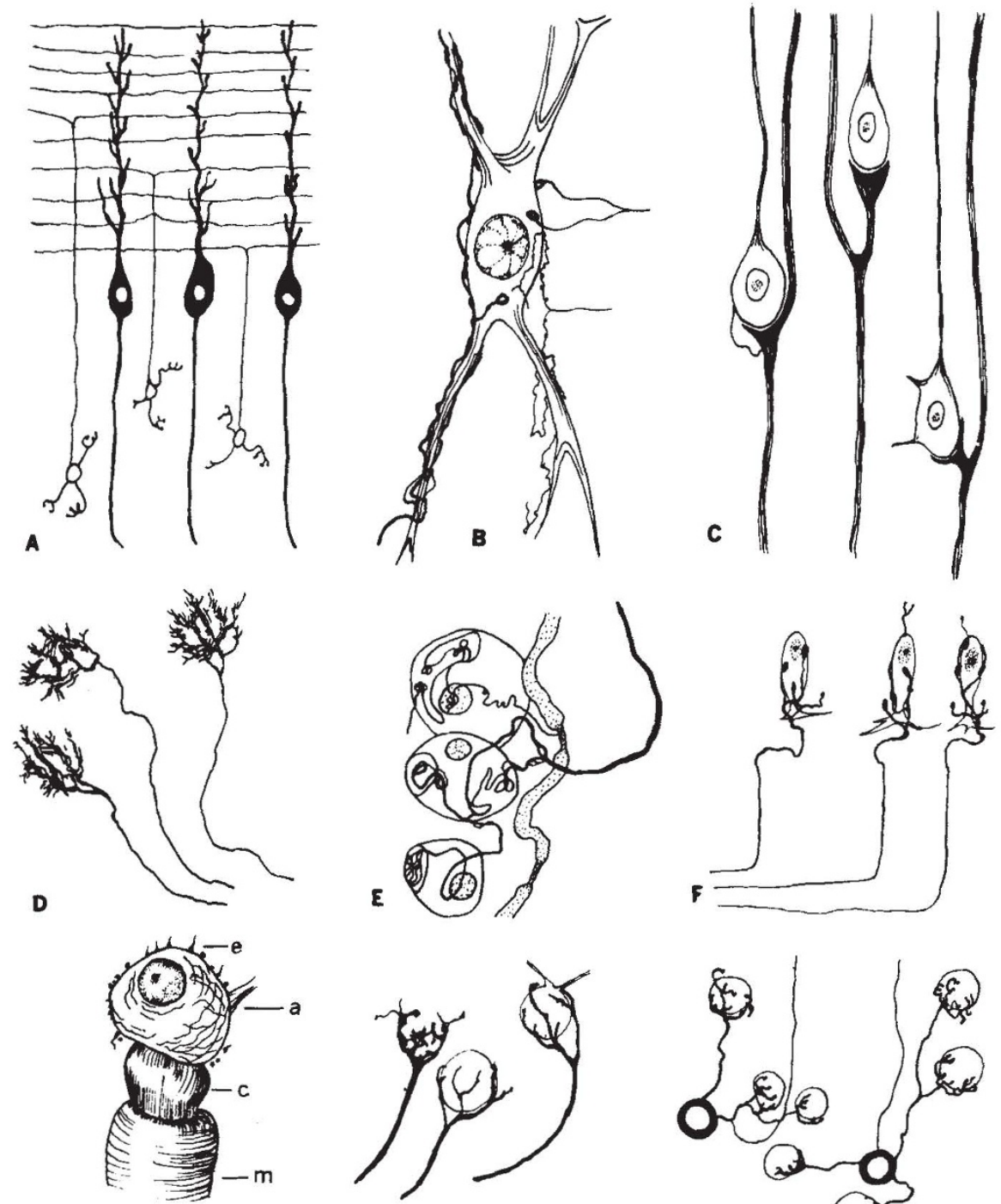

G

Illustrations of synaptic morphology taken from various sources: a drawing from one of the contributions to Concepts of Communication: Interpersonal, Intrapersonal and Mathematical, edited by Edwin F. Beckenbach and Charles B. Tompkins (Wiley, New York, 1971; f9.50). some understanding of it, viz. the technical managers, research scientists, technologists and company secretaries whose activities may be affected by the existence of patent protection. The bridging of this language gap is very important in rendering this subject of industrial property into an acceptable frame.

In the words of the publishers, this book is "primarily a book of ready reference to the basic principles and practice of patent laws for use by those involved with commissioning the filing and prosecution of patent applications at home and abroad, and with dealing in that class of industrial property". Yet this handbook, based on a series of lectures, is still written in patentese whose very existence and use make the topic so difficult to grasp. It is admittedly not so easy to present a good survey on the patent world without using the jargon of its trade, but it can be done as Lees has shown in his earlier book.

The present author has certainly succeeded in producing a competent survey of the British patent system with some brief references to the systems of the major industrial countries (except the USSR and the countries of Eastern Europe). A synopsis of foreign patent laws is given in a shorthand form in an appendix. Much of the information is refreshingly up-to-date, such as the reference to the new Japanese regulations of 1971 and the recommendations of the Banks Committee, although the knighthood conferred on its chairman must have come too late for inclusion in the book.

The book is well produced though some minor inaccuracies were noted, for example, the dating of the Statute of Monopolies on p. 1 which is generally referred to as being of 1623 , or the spelling of the new German patent publications which should read "Offenlegungsschrift" on p. 33. A glossary of more than 60 terms of patentese is a very useful addition to this slim volume.

Felix Liebesny

\section{Mediaeval Physics}

Physical Science in the Middle Ages. By Edward Grant. Pp. xi+128. (Wiley: New York and London, November 1971.) $£ 3.50$ cloth; $£ 1.75$ paper.

THE title of this book is rather misleading, for it suggests a wider coverage than is in fact given. Professor Grant has realized the great extent of the material before him, and has decided to concentrate on the Aristotelian tradition in the later Middle Ages. This immediately means that we are told virtually nothing of the work of such men as Grosseteste, Jordanus, Petrus Peregrinus, Roger Bacon and Witelo. Grant's first twenty- 